OPEN ACCESS

Edited by:

Johan Berlin,

University West, Sweden

Reviewed by:

Lars Frelin,

Karolinska Institutet (KI), Sweden

Jörn Boehnke,

University of California, Davis,

United States

John James Kiefer,

University of New Orleans,

United States

*Correspondence:

Jon Reiersen

jon.reiersen@usn.no

Specialty section

This article was submitted to

Disaster Communications,

a section of the journal

Frontiers in Communication

Received: 25 November 2021

Accepted: 01 February 2022

Published: 02 March 2022

Citation:

Reiersen J, Roll K, Williams JD and Carlsson M (2022) Trust: A

Double-Edged Sword in Combating

the COVID-19 Pandemic?

Front. Commun. 7:822302.

doi: $10.3389 / f c o m m .2022 .822302$

\section{Trust: A Double-Edged Sword in Combating the COVID-19 Pandemic?}

\author{
Jon Reiersen*, Kristin Roll, Jesse Dylan Williams and Michael Carlsson \\ School of Business, University of South-Eastern Norway, Kongsberg, Norway
}

We examine the impact of trust in combating the SARS-CoV-2 virus, that can cause COVID-19. Under normal circumstances trust is a crucial component for society to function well, but during a pandemic trust can become a double-edged sword. On the one hand, a high level of trust in society may lead to greater acceptance among citizens for public measures that aim to combat a virus. If people believe that their respective governments implement unbiased and well-informed measures, and people also believe that their fellow citizens will follow these measures, this may lead to a high general compliance in society and less people will be infected. On the other hand, trust may affect people's perception of risk and hence their behavior. If people believe that most people are trustworthy, they may be less willing to think of everyone else as a potential health threat. If people also trust the government to manage the pandemic in a competent way, their perception of the risks related to the pandemic weaken. Taken together, this may lead people in high trust societies to consider personal protective measures less important, and more people will be infected. The ambiguous effect trust may have on the outcome of a pandemic calls for a closer empirical analysis. Drawing on data from 127 countries we find that the number COVID-19 deaths decrease with trust in government and trust in science, while the number COVID-19 deaths increase with social trust. Implications of these findings for risk communication and management during a pandemic are discussed.

Keywords: trust, risk perception, pandemic, public compliance, COVID-19

\section{INTRODUCTION}

On December 31, 2019, the Wuhan Municipal Health Commission reported a cluster of pneumonia cases in China. The outbreak of the disease was later identified as caused by a new virus, SARS-CoV-2-a virus that can lead to COVID-19. The emergence of the new virus rapidly escalated to a public health emergency of international concern. On March 11, 2020, the World Health Organization declared that the world was faced with a considerable threat, and the COVID-19 outbreak was officially characterized as a pandemic. This in turn led to a variety of measures put in place by governments worldwide to control and contain the spread of the virus. Governments have responded in various manners ranging from recommended hygiene practices and use of face masks through to social distancing and complete lockdowns of society. Despite strong measures, millions have been infected and more than 5 million have died due to COVID-19 (by October 29, 2021). 
Human behavior critically affects how a pandemic develops. An essential contribution to the successful management of a pandemic is that most people comply with the health authorities' recommendations. If people adopt good hygienic routines, keep physical distance and get vaccinated (when an effective vaccine becomes available), a pandemic can be brought under control. It seems to be widely believed that trust is a critical factor to achieve this. The argument put forth by commentators and others is that trust increases the likelihood that people follow the authorities' recommendations and carry out personal protective measures. Norway can serve as an example. In a comparative perspective, Norway has had relatively few infections and deaths as a result of COVID-19. ${ }^{1}$ An independent Coronavirus Commission report (NOU, 2021, p. 6) assessing the Norwegian authorities' management of the COVID-19 pandemic attributes the high level of social trust in Norway as a strength in combating the virus (but without doing any serious attempt to document this empirically). ${ }^{2}$ Prior to the publication of the report, the Prime Minister of Norway had proclaimed in a televised speech (broadcasted March 18, 2020) that the high level of trust in Norway provided the country “... with an advantage throughout the pandemic, more effective than any weapon and more valuable than any oil fund". 3

An important reason for why trust is generally seen as a critical factor in combating a pandemic is probably the extensive research showing that trust is an important condition for a society to function well (see e.g., Fukuyama, 1995; Yamagishi, 2011; Algan and Cahuc, 2013, among many others). When people trust each other, economic transactions run more smoothly (Torsvik, 2000), collective action problems are more easily solved (Ostrom, 2003), society is more inclusive and open (Fukuyama, 1995; Lazzarini et al., 2008; Yamagishi, 2011), there is less corruption and better governance (Rothstein, 2011), and people generally are happier and have better health (Putnam, 2000; Uslaner, 2002). Based on available evidence it is fairly safe to conclude that under normal circumstances, trust is a valuable asset for a society. A pandemic, however, does not represent "normal circumstances". Recent research has shown that trust is not a panacea that guarantees successful crisis management, including crisis management during a pandemic.

\footnotetext{
${ }^{1}$ By October 29, 2021, Norway has 164 COVID-19 deaths per million people. In comparison, the country with most confirmed COVID-19 deaths is Peru, with 6,002 deaths per million people. The US has 2,240 deaths per million while the average for the world is 634 deaths per million people (Ritchie et al., 2021).

${ }^{2}$ Social trust varies widely across countries. Empirical research investigating the relationship between trust and various measures of quality of society usually draws on data from the World Value Survey (WVS), where trust is derived from the dichotomous question: "Generally speaking, would you say that most people can be trusted or that you need to be very careful in dealing with people?" with the response alternatives "Most people can be trusted" and "Need to be very careful." On average, in the world as total, around $25 \%$ state that most people can be trusted. On top of the list we find Norway with a score of $74 \%$. In comparison, The United States has a trust score of around 38\%, while France and Spain are down at around $18 \%$. Countries showing low levels of trust are Romania (7\%), Colombia (4\%), and the Philippines (3\%) (WVS, Wave Five and Six 2005-2013).

${ }^{3}$ Norway's oil fund was created after Norway discovered oil in the North Sea in the late 1960. The fund is now one of the world's largest funds, with over US 1.3 trillion in assets which is about US 245,000 per Norwegian citizen.
}

Trust plays an important role in peoples' assessment of risk and thus their behavior (Siegrist and Cvetkovich, 2000; Earle, 2010). Terpstra (2011) studied Dutch citizens' flood preparedness and found that a higher level of trust in flood risk experts reduced both the citizens' perception of the likelihood of flooding and the amount of fear caused by the risk of flooding. Both mechanisms hampered the citizens' flood preparedness. Likewise, Wong and Jensen (2020) show that that trust can be a barrier to the desired behavior from the governments' point of view. They report that the strong trust in the governments' crisis management led the citizens to accept the governments' advice and recommendations to a lesser extent during the COVID-19 pandemic in Singapore. Similar findings are also noted from other countries. Wollebæk et al. (2020) found that Norwegians that strongly believe that most people can be trusted are less worried about the consequences of the COVID-19 pandemic and they are also less willing to comply with the governments' infection control measures. At the same time, they also found that the amount of trust Norwegians have in the government is positively related to compliance with the governments' recommendations. Those who trust the government a lot follow more of the recommendations compared to those who have little trust in the government. That is, social trust and trust in government seem to have opposite effects on the acceptance of measures to reduce COVID-19 cases. Similar results are noted from Switzerland. Siegrist et al. (2021) carried out a survey in March-April 2020, to study how different dimensions of trust influence peoples' risk perception and their acceptance of the implemented measures to control the pandemic. They found that peoples' fear associated with COVID-19 is negatively correlated with social trust, but they also found that peoples' acceptance of the implemented measures to control the pandemic was positively correlated with trust in government. Again, social trust and trust in government seem to have opposite effects.

Drawing on data on social trust and COVID-19 deaths for 37 countries, Arachchi and Managi (2021) found that social trust was associated with more COVID-19 deaths, where they also controlled for several other variables. Elgar et al. (2020) reach the same conclusion when analyzing cross-national differences in COVID-19 deaths for 84 countries during the early phase of the pandemic. However, Helliwell et al. (2021) report the opposite result when analyzing COVID-19 deaths in 163 countries and using income inequality as a proxy for social trust. ${ }^{4}$ They found that inequality of income is a strong predictor of a higher COVID-19 death rate. Helliwell et al. (2021) also found that little trust in public institutions is associated with more COVID-19 deaths. Bargain and Aminjonov (2020) look at the impact of trust in policy makers on peoples' compliance to health policy rules. In particular, they examine how trust at regional level in Europe effects mobility related to non-necessary activities around the time of lock-down announcement (March 2020). They find that the decline in mobility is significantly stronger in high-trust regions in Europe.

${ }^{4}$ Many studies have noted that social trust is generally lower in countries where income inequality is higher. 
Research from previous pandemics also note the importance of trust for people's willingness to comply with the governments' recommendations and for the outcome of a pandemic. Studies from several countries have found that people who trust medical and political authorities, as well as the media, were more likely to adopt the recommended behavior in order to control the 20092010 pandemic of swine influenza, caused by the H1N1 virus (Rubin et al., 2009; Gilles et al., 2011; Prati et al., 2011; Freimuth et al., 2014; Chuang et al., 2015). Tang and Wong (2005) report that lack of trust in the government was strongly associated with public anxiety during the 2003 SARS outbreak in Hong Kong, while Blair et al. (2017) found that those who had less trust in the government were less likely to take precautions during the 2014-2016 Ebola outbreak in Liberia and Congo.

Taken together, available evidence provides mixed results when it comes to how trust affects the outcome of a pandemic and it also demonstrates that different dimensions of trust can affect people's assessment of risk, their behavior, and the outcome of a pandemic in very different ways. Analyses of how trust is related to the outcome of a pandemic should therefore distinguish between different types of trust and also be open to the possibility that different types of trust can have different effects on how people perceive risk and react to a pandemic (Poortinga and Pidgeon, 2003; Siegrist and Zingg, 2014; Wong and Jensen, 2020; Siegrist and Bearth, 2021; Siegrist et al., 2021). In this study we examine how trust in fellow citizens, trust in government and trust in science affect the number of confirmed COVID-19 deaths. To investigate this issue, we collected data for 127 countries around the world. Building on previous literature we also include other variables that are likely to affect the outcome of a pandemic. These variables are discussed in more detail in the next section, together with a closer examination of the relationship between trust and human behavior during a pandemic, and the hypotheses we can derive from this examination.

\section{MATERIALS AND METHODS}

\section{Social Trust and Cooperation During a Pandemic}

As noted, research examining the impact of trust for the outcome of a pandemic have provided mixed results. This is not surprising if we look at what theory can tell us about how trust is likely to affect behavior in a pandemic. Fighting a pandemic has many of the same characteristics as a public goods game. If everyone takes precautions, adopt good hygienic routines, keep physical distance and so on, the pandemic can be brought under control, which is in everyone's best interest. However, if people generally believe that everyone takes their precautions (cooperate), it is tempting to free-ride on the joint efforts of others. In that case, one saves oneself from the cost of taking precautions, at the same time as the pandemic is brought under control as a result of the efforts of others. But of course, if everyone acts as free-riders there will be no public goods-that is, the virus spreads and the society faces a pandemic.

Several experiments with the public goods game show, however, that a large majority are generally willing to contribute and to cooperate, and a minority act as unscrupulous free-riders. Conditional cooperation seems to be the predominant behavioral pattern for contributions in experimental public goods games (Fischbacher et al., 2001; Fehr and Gächter, 2002; Herrmann and Thöni, 2009; Volk et al., 2012). People are generally willing to cooperate in public goods games as long as they trust others to do the same. This points in the direction that high social trust makes it easier to fight a pandemic, since people are willing to take the necessary precautions as long as they trust others to do the same.

On the other hand, this reasoning does not take into account that in a pandemic the individual is also a potential carrier of a virus. As noted by Siegrist et al. (2021), what matters for the individual's action is not only what one thinks about the actions of others, but also what one thinks about the risk of others carrying a virus. If people believe that most people are trustworthy, they may be less willing to think of everyone else as a potential health threat (that they carry a virus), and they will consider personal protective measures less important. More people will be infected, and the pandemic is more difficult to fight.

\section{The Role of Trust in Government and Trust in Science}

There are also mechanisms pointing in the direction that trust in government and trust in science has an ambiguous impact on the outcome of a pandemic. When people have to make choices faced with a situation they are unfamiliar with, they usually lack the knowledge they need to make an informed decision. A pandemic typically represents such a situation. Most people do not have sufficient information on how to behave, especially during the initial phase of a pandemic outbreak. People have to rely on information provided by others when making a decision. If people generally trust those who give the government scientific and professional advice, and if people believe that the government implements unbiased and well-informed measures, this can lead to greater acceptance among citizens for the measures put in place by the government to combat a virus.

However, trust in the government and trust in science can have the opposite effect, as showed by Wong and Jensen (2020). High trust in the government and other authorities can lead to an underestimation of the risk of a pandemic and a perception that individual action is not required. People may believe that the government will do the necessary effort to combat the pandemic. High trust in the government and other authorities may in other words crowd out peoples' motivation to carry out individual sacrifices.

To sum up: During a pandemic, different types of trust can affect people's behavior in different ways. It is therefore difficult to determine from the outset whether trust is detrimental or beneficial in fighting a pandemic. We must leave it to our empirical analysis to determine what effect the different dimensions of trust have on the outcome of the COVID19 pandemic.

\section{Empirical Specification}

To investigate how trust affects the outcome of a pandemic, we estimate a multivariable regression model. A multivariable model allows us to incorporate other relevant explanatory variables, expected to affect the outcome of a pandemic. In addition 
to the key explanatory variables of trust we include, gross domestic product per capita, population density, median age of the population, numbers of bordering countries, a health index and we control for continent. To assist the interpretation of the results, the estimated model is specified on log-log form, which derives the elasticities directly from the parameters.

The estimated model is given as follows:

$$
\begin{aligned}
& \ln \left(\text { DPMP }_{i}\right)=\beta_{0}+\beta_{\text {TGOV }} \ln \left(\text { TRUSTGOV }_{i}\right) \\
& +\beta_{T S O S} \ln \left(\text { TRUSTSOS }_{i}\right)+\beta_{\text {TSCI }} \ln \left(\text { TRUSTSCI }_{i}\right) \\
& +\beta_{G D P} \ln \left(G D P_{i}\right)+\beta_{P O P} \ln \left(\text { POPDEN }_{i}\right) \\
& +\beta_{A G E} \ln \left(\text { MEDAGE }_{i}\right)+\beta_{\text {BORDC }} \ln \left(\text { BORDC }_{i}\right) \\
& +\beta_{H I} \ln \left(\text { HINDEX }_{i}\right)+\sum_{C} \beta_{C}\left(C O N T I N E N T_{C}\right)
\end{aligned}
$$

where the dependent variable, $D P M P_{i}$, is the total confirmed COVID-19 deaths per million people for country $i^{5}$ The numbers are retrieved from Ritchie et al. (2021), on September 28, 2021.

Our key explanatory variables TRUSTGOV $i$, TRUSTSOS $_{i}$, and TRUSTSCI $I_{i}$ are measuring country is level of trust in the government, trust in society and trust in science. The three variables are derived from the indicator included in the Wellcome Global Monitor 2018 (Wellcome Trust and The Gallup Organization Ltd., 2019). In their yearly global survey, they are asking the following questions:

- Trust in government: How much do you trust the national government in this country.

- Social trust: How much do you trust people in your neighborhood.

- Trust in Science: How much do you trust scientists in this country.

Respondents were provided with the following six answer alternatives: A lot, some, not much, not at all, don't know and neutral. The value that has been assigned to these variables is the share of respondents who answered with the alternatives "A lot" or "Some". Given the ambiguous relationship between the three different dimensions of trust and the number of COVID19 deaths, as discussed above, we do not have a straightforward hypothesis on the direct relationship between the degree of trust and the outcome of the COVID-19 pandemic.

$G D P_{i}$ measuring the gross domestic product per capita in country $i$ and is expressed in constant 2017 international dollars and converted by purchasing power parity. The numbers are taken from the World Bank (2021a). Measures to limit the spread of the coronavirus have major consequences for the economy. Rich countries are more capable of enduring prolonged economic

\footnotetext{
${ }^{5}$ An alternative response variable, contracted cases per million people, were also considered but deemed unreliable for the analyses due to underreporting of this variable. There is a wide variation in testing practices leading to underreporting of cases that do not necessarily represent the actual situation. A recent study (Rahmandad et al., 2021) has estimated that the ratio of actual to reported cumulative cases is 7.03 , corresponding to 465 million undetected cases. The occurrence of asymptomatic infections can also explain a large proportion of underreporting. In comparison, it is estimated that the actual number of deaths is 1.44 times higher than official reports.
}

downturn and are therefore also more likely to implement more stringent restrictions to mitigate the transmission of the virus. Hence, we expect fewer COVID-19 deaths in countries with a higher GDP per capita.

POPDEN $_{i}$ measuring population density in country $i$, and is defined as population per sq. $\mathrm{km}$ of land area. This variable is also taken from the World Bank (2021b). OECD (2020) emphasize population density as a contributing factor to the effectiveness of containment strategies. Considering that social distancing is a dominant containment measure, it is expected that this will be more effective in countries and communities with lower population density. We therefore expect that countries with a higher population density will experience a higher rate of COVID-19 deaths.

$M E D A G E_{i}$ measuring the median age in country $i$, and indicates the point of age in which half of the population is younger, and half of the population is older. The numbers are retrieved from the United Nations (2021). It is well documented that the likelihood of becoming seriously ill and dying from COVID-19 is increasing with age (OECD, 2020). Medina (2020) shows for example that patients over the age of 60 are 8.15 times more likely to die from COVID-19 than patients under the age of 60 . Populations with more elderly people have more individuals at risk of dying from the virus, and we therefore expect that a higher median age will result in a higher rate of COVID-19 deaths.

$B O R D C_{i}$ measuring the number of countries bordering country $i$, and is defined as the number of land boundaries each country has on a ratio scale where zero is the lowest value (a value of 0 signifies that a country has no land boundaries ${ }^{6}$ ). The numbers are taken from World Factbook (2021). Analysis of the Ebola outbreak shows that cross-border exchange of preparedness and response co-ordination is imperative (Olu et al., 2020). The implementation of border control measures in response to the pandemic will probably be more difficult for countries with more bordering countries, and we therefore expect that a higher number of bordering countries will result in a higher number of COVID-19 deaths.

HINDEX $X_{i}$ is a health index compromised by 13 indicators including life expectancy, physician rate, mortality rates and free/universal healthcare which are important components of health equity (Hudson International Group, 2021). The index value is a weighted average converted to a score on a ratio scale ranging from 0 to 1 where 0 is the lowest score, and 1 is the highest score. The quality of the health care system is a critical factor when a country is hit by a pandemic. ${ }^{7}$ Access to equipment, medicines, the number of doctors and nurses per inhabitant, public funded vs. private provision of health services and a number of other factors contribute to determine the quality of the health care system. Countries with a high level of health equity should be better equipped to treat the population including those most marginalized and vulnerable in the face of a pandemic (OECD, 2020). A Mexican study found, for example, the lack of

\footnotetext{
${ }^{6}$ To facilitate the logarithmic transformation, we are following Weninger (1998), and modify zero-value arguments by replacing them with arbitrarily small values. ${ }^{7}$ See OECD (2020) for a more thorough analysis and discussion.
} 
TABLE 1 | Summary statistics for the sample variables.

\begin{tabular}{|c|c|c|c|c|c|c|}
\hline & COVID-19 deaths & Mean & Std. Dev. & Min & Max & Source \\
\hline Number of deaths per million (DPMP) & & 1,090 & 1,015 & 1 & 5,975 & Ritchie et al., 2021 \\
\hline Trust in the government (TRUSTGOV) & \pm & 0.514 & 0.188 & 0.110 & 0.990 & Wellcome Global Monitor \\
\hline Trust in society (TRUSTSOS) & \pm & 0.730 & 0.142 & 0.310 & 0.960 & Wellcome Global Monitor \\
\hline Trust in science (TRUSTSCl) & \pm & 0.746 & 0.132 & 0.400 & 0.980 & Wellcome Global Monitor \\
\hline Gross domestic product per capita (GDP), 2019 & - & 16,629 & 21,477 & 412 & 114705 & World Bank \\
\hline No of bordering countries (BORDC) & + & 4.21 & 2.26 & 0.00 & 14.00 & The World Factbook \\
\hline Population density (POPDEN) & + & 113 & 126 & 2 & 669 & World Bank \\
\hline Median age (MEDAGE) & + & 31.60 & 9.10 & 15.80 & 47.10 & United Nations \\
\hline Health index (HINDEX) & - & 0.658 & 0.253 & 0.010 & 0.940 & $\begin{array}{l}\text { Hudson International } \\
\text { Group }\end{array}$ \\
\hline Africa & & 0.234 & 0.425 & 0 & 1 & \\
\hline Asia & & 0.224 & 0.419 & 0 & 1 & \\
\hline Australia & & 0.019 & 0.136 & 0 & 1 & \\
\hline North America & & 0.327 & 0.471 & 0 & 1 & \\
\hline South America & & 0.103 & 0.305 & 0 & 1 & \\
\hline
\end{tabular}

health services to the indigenous population put them at a higher risk of vulnerability in the presence of the COVID-19 pandemic (Díaz de León-Martínez et al., 2020). We therefore expect that a higher health index value will result in fewer COVID-19 deaths.

Finally, CONTINENT is a dummy variable included to control for continent-specific effects. The countries have been categorized into one of the following continents: Asia, Africa, North America, South America, Australia or Europe. In our estimated model the default category consists of countries in Europe.

Table 1 summarizes the basic hypotheses and structure that guide our analysis together with some descriptive statistics. Because of the ambiguous relationship between the different dimensions of trust and the number of COVID-19 deaths, these variables are marked with \pm in column two. The other variables included in our analysis have a more unambiguous expected effect on the number of COVID-19 deaths, and this is marked with either + (the variable is expected to have an increasing effect on the number of COVID-19 deaths) or-(the variable is expected to have a decreasing effect on the number of COVID-19 deaths) in column two in Table 1.

As Table 1 illustrates, the dataset used in the study is built from several sources. Our sample started out with 127 observations/countries, but due to missing observations in several of the explanatory variables (among others the trust variables), our sample reduces to 107 observations. Stata 15 software was used for all analyses.

\section{RESULTS}

Before estimation, a classical additive disturbance term was appended to Equation (1). The empirical model was first estimated using OLS. A Breusch-Pagan test for the null hypotheses of homoskedasticity was however rejected at a 0.001 level of significance, indicating problems with heteroskedasticity
TABLE 2 | COVID-19 deaths per million people: Regression results.

\begin{tabular}{lcccc}
\hline & Coef. & $\begin{array}{c}\text { Robust std. } \\
\text { Err. }\end{array}$ & t-value & $\boldsymbol{p}$-value \\
\hline $\begin{array}{l}\text { Trust in government } \\
\text { (TRUSTGOV) }\end{array}$ & -0.553 & 0.247 & -2.240 & 0.028 \\
$\begin{array}{l}\text { Trust in society } \\
\text { (TRUSTSOS) }\end{array}$ & 2.072 & 0.819 & 2.530 & 0.013 \\
$\begin{array}{l}\text { Trust in science } \\
\text { (TRUSTSC) }\end{array}$ & -3.580 & 1.427 & -2.510 & 0.014 \\
$\begin{array}{l}\text { Gross domestic } \\
\text { product per capita }\end{array}$ & 0.299 & 0.152 & 1.970 & 0.052 \\
$\begin{array}{l}\text { (GDP) } \\
\text { No of bordering }\end{array}$ & 0.352 & 0.203 & 1.730 & 0.087 \\
$\begin{array}{l}\text { countries (BORDC) } \\
\text { Population density }\end{array}$ & -0.056 & 0.097 & -0.580 & 0.565 \\
(POPDEN) & & & & \\
Median age (MEDAGE) & 2.003 & 0.946 & 2.120 & 0.037 \\
Health index (HINDEX) & 0.430 & 0.322 & 1.340 & 0.185 \\
Africa & -0.707 & 0.676 & -1.050 & 0.298 \\
Asia & 0.023 & 0.470 & 0.050 & 0.962 \\
Australia & -1.382 & 1.684 & -0.820 & 0.414 \\
North America & 0.440 & 0.404 & 1.090 & 0.279 \\
South America & 0.915 & 0.451 & 2.030 & 0.045 \\
Constant & -3.988 & 4.256 & -0.940 & 0.351 \\
\hline & & & & \\
\hline
\end{tabular}

in the data. ${ }^{8}$ To ensure that the assumption of constant variance is fulfilled, the model was reestimated with robust standard errors. ${ }^{9}$

The estimated parameters are reported in Table 2. Most of the slope parameters are statistically significant at the 0.05 level. The $R^{2}$-value for the estimated model is 67.56 and indicates that the data fits the model well.

\footnotetext{
${ }^{8} \mathrm{The} \mathrm{chi}^{2}$-value of the test is found to be 29.05 .

${ }^{9} \mathrm{We}$ also conducted a statistical test to check for normality-distributed errors, which showed that this assumption is met.
} 
The main focus of this paper is the effect of different dimensions of trust in combating the COVID-19 pandemic. The first three lines of Table 2 report to what degree trust in government, trust in society and trust in science effect a countries' deaths caused by COVID-19. All three trust variables are found to be significant at a $5 \%$ level, indicating that the three dimensions of trust included in the analysis are important.

Trust in science is found to be most important trust variable with an estimated parameter of -3.6 , indicating that a $1 \%$ increase in this type of trust level will decrease COVID-19 related deaths by $3.6 \%$. We believe that vaccination is part of the explanation for this result. When we collected data for the number of COVID-19 deaths (September 28, 2021), vaccines were available in many countries, particularly in the rich industrialized part of the world. We know from studies of previous pandemics, such as the SARS epidemic and the 2009/10 H1N1 influenza, that trust in medical experts and organizations had a positive impact on vaccination behavior. In countries with little trust, vaccine uptake remained low (see Siegrist and Zingg, 2014, for a review of studies). This is not surprising. There is reason to believe that the public initially has limited knowledge and information about a new vaccine-how safe they are, if they have been adequately tested, how effective they are and so on. People must therefore rely on the information provided when deciding whether to be vaccinated. Trust becomes important regarding whom to believe. Information from the scientific community is therefore mediated by trust, and trust becomes crucial for the publics' reception and acceptance (Siegrist and Zingg, 2014; Warren and Lofstedt, 2021). If the scientific community recommend vaccination, and people generally believe that those who make up the scientific community are competent and objective, more people will get vaccinated, and the death rates go down. In the same way, trust will also be important for the public's acceptance of other preventive measures that the scientific community recommends in order to gain control of a pandemic.

Trust in government is also found to be positive and significant, however the estimated parameter is less than the parameter for trust in science. A $1 \%$ increase in the trust in government level decreases the COVID-19 death rate by $0.6 \%$. Many of the advice and measures that health experts and other scientists have proposed through the COVID-19 pandemic have been communicated to the public through different governmental agencies. The results from our analysis supports the idea that the extent to which the public has followed the governments' advice and taken the necessary precautions depends on their trust in the government. This finding is in line with the findings in Bargain and Aminjonov (2020), Arachchi and Managi (2021) and Helliwell et al. (2021). We thus find little support for our alternative hypothesis that high trust in the government crowds out people's willingness to carry out personal sacrifices, and that they leave it to the government to do what it takes to bring the pandemic under control.

Compared to trust in science and trust in government, trust in society is found to have opposite effect on the number of COVID19 deaths. A $1 \%$ increase in the level of social trust worsen the consequences of the COVID-19 pandemic, increasing the death rate by $2.1 \%$. This lends support to the findings referred to above, illuminating that social trust may act as a barrier to behavior that is necessary to reduce the spread of a virus. In countries with high social trust, people generally believe that most people are trustworthy, that they take their precautions and that they stay home if they are sick. Hence, people in high trust societies may be reluctant to think of others as a potential health threat and they may consider personal protective measures less important.

In contrast to our expectation, GDP per capita is found to have a negative effect on the number of COVID-19 deaths. The result is almost significant at $5 \%$ with a $p$-value of 0.052 . We believe that our findings could be related to the fact that the pandemic is still ongoing and that countries are at different stages of the pandemic. Except from China, high-income countries westernEurope were hit first by the virus. At the time of writing (October, 2021) the COVID-19 pandemic is still ongoing with full force in many poor countries, especially in Africa and parts of Asia.

Number of bordering counties are found to have a positive effect on the number of COVID-19 deaths at a 10\% level of significance. This was supported by previous research (Olu et al., 2020; Helliwell et al., 2021), which shows that the implementation of border control measures is more difficult for countries with a high number of bordering countries.

Age is also found to have a strong positive effect on the number COVID-19 deaths. A $1 \%$ increase in the median age will increase COVID-19 related deaths by $2 \%$. This is in line with findings in Medina (2020), OECD (2020), and Arachchi and Managi (2021). The virus has disproportionately hit older people and higher death rates from COVID-19 among older people are reported from all over the world.

Our results indicate that there is some continent specific effect. Keeping everything else equal, there is no significant difference in the COVID-19 death rate in Europe, North America, Australia, Asia, or Africa. South America is however found to have a continent-specific effect with a significantly higher death rate. This is most likely explained by the particular high death rates in Peru, Brazil, Argentina and Colombia. At the time of writing, these four South American countries are among the 15 countries in the world with the highest number of COVID-19 deaths per million people.

The variables population density and health index are not found to have a significant effect at any satisfactory level of significance on the number of deaths caused by COVID-19.

\section{DISCUSSION}

The COVID-19 pandemic has posed a serious threat to the world community. At the time of writing, over five million have died, millions of people have been infected and nations, firms and individuals have been subjected to great strain (IMF, 2021; WHR, 2021). It is an overriding goal for the authorities to bring the pandemic under control. Strong measures have been implemented by governments in most countries. How a pandemic develops, however, depends critically on how people behave and whether they are willing to follow the authorities' measures and recommendations. It is widely believed that trust is 
a key factor in gaining public acceptance of government measures (Siegrist and Zingg, 2014). In societies with little trust, it is difficult to mobilize the necessary collective efforts to gain control of a pandemic. However, our analysis shows that trust is not a panacea for good pandemic management. Trust has many dimensions, and previous studies show that some forms of trust can be a barrier to good pandemic management (Wong and Jensen, 2020; Arachchi and Managi, 2021; Siegrist et al., 2021). Our results support these findings.

\section{The Role of Trust}

Trust and risk are closely linked, and social trust has been found to be negatively correlated with risk perception across a broad range of situations (Siegrist and Zingg, 2014). During a pandemic, high social trust may lead to less risk-reducing measures. When people trust each other, they are probably less willing to consider others as a potential health threat, and they will show less precautionary behavior (i.e., keep physical distance). This may be the reason why we find that social trust is negatively associated with the number of COVID-19 deaths. ${ }^{10}$

There are also studies that show that trust in government and trust in science is negatively correlated with risk perception and that this type of trust crowds out peoples' willingness to implement precautionary measures (Wong and Jensen, 2020). Our results do not support this. We find that trust in government and trust science is associated with fewer COVID-19 deaths. Our results therefore suggest that social trust and trust in government and science have opposite effects.

Our analysis also revealed that COVID-19 deaths increased with number of bordering countries, median age and GDP per capita. The last effect probably catches up the fact that rich industrialized countries were hit first by the COVID-19 pandemic and other regions are still in the midst of the pandemic. In addition, South America is found to have a significantly higher death rate compared to the rest of the world.

\section{Trust, Risk Governance, and Communication}

The early phase of a pandemic typically represents a situation where people have to make decisions without having a full knowledge of the consequences of the choices they make. Since there is a clear connection between risk perception and behavior, it is important for health experts and government agencies to provide updated information about possible hazards and risks, and thus enable the public to make informed decisions.

As Warren and Lofstedt (2021) emphasize, peoples' risk perceptions are shaped by government communication strategies. Understanding what affects people's risk perception is therefore critical when the government formulate their communication strategy. However, this knowledge is of little value if people are still not willing to listen to the government. If people do not trust the government, it is difficult for them

\footnotetext{
${ }^{10}$ Our analysis covers roughly the first 18 months of the pandemic. As one reviewer suggests, the effect of social trust may change over the course of the pandemic. Even though people trust each other a lot, they may gradually learn that also trustworthy individuals represent a potential health threat during a pandemic. Hence, over time people will show more precautionary behavior also in high trust societies.
}

to reach out and correct potential distortions in people's risk perception. As a consequence, people may take wrong preventive actions or that they refuse to follow the recommended behavior. Our study shows that countries where people have little trust in government and little trust in science have more COVID-19 deaths.

The implication of this is as easy as it is difficult. It is important to establish trust in health experts before an outbreak of a pandemic. When a health crisis emerges, the public will have an urgent need for information on how to act. Who they turn to for information depends on who they trust. This means that it is too late for the government and health experts to try to build trust after a pandemic has begun to develop. When the crisis hits, people need to be convinced of who really are the experts among many proclaimed "experts". As Siegrist et al. (2021) notes: "Building the basis for social trust already begins before a pandemic. Ill-prepared government agencies may not be in a good position to be trusted by the public" (p. 798).

Concerning social trust, that is, how many people believe that most people are trustworthy, the general belief seems to be that this form of trust is also unambiguously good for fighting a pandemic. However, our results suggest that social trust is associated with more deaths as a result of COVID-19. We cannot say with certainty what explains this, but a possible interpretation is that when people generally believe that most people are trustworthy, they may be less willing to think of everyone else as a potential health threat and they will consider personal protective measures less important. More people will be infected, and the pandemic is more difficult to fight.

Nevertheless, we cannot conclude from this that social trust makes it difficult to combat a pandemic. As noted above, fighting a pandemic has many of the same features as a public goods game. If everyone takes precautions, adopt good hygienic routines, keep physical distance and so on, the pandemic can be brought under control, which is in everyone's best interest. But, if people generally believe that everyone takes their precautions (cooperate), it is tempting to free-ride on the joint efforts of others. Fortunately, we know from experiments that people are generally willing to cooperate in public goods games as long as they trust others to do the same (e.g., Fischbacher et al., 2001; Fehr and Gächter, 2002; Herrmann and Thöni, 2009; Volk et al., 2012). This is how social trust can help in fighting a pandemic. People are more likely to accept pandemic-related restrictions and take the necessary precautions when they have a belief that most others will do the same. It is therefore important that the government, in their communication with the public, build further upon this belief. As Warren and Lofstedt (2020: p. 7) notes: "Promoting social solidarity and collectivism is significant when requiring or requesting that groups undertake altruistic actions or accepts limitations to freedom (...)." The government can contribute to this by referring to examples and stories that illustrate that most people accept and follow up on the measures that have been decided. Too much focus on those who do not comply with the measures can be counterproductive since it easily crowds out people's motivation to make personal sacrifices for the greater benefit of society. Avoiding a "us vs. them" mindset is important for building social trust and creating the necessary 
collective effort needed to combat a pandemic (Warren and Lofstedt, 2021).

At the same time as the government must strive to maintain and build social trust, it is also critical that they manage to make the citizens aware that those they trust can be a potential health risk, i.e., that they can be carriers of a virus. The authorities must therefore try to communicate a kind of two-part message: Do what it takes to fight the pandemic and trust that most others will do the same- - but do not trust that most others are virus free during a pandemic.

\section{The Impact of the Pandemic on Trust}

As discussed in this article, many factors contribute to influencing the outcome of the COVID-19 crisis. Along with the vaccine, trust is a key factor. At the same time, there is reason to believe that the pandemic has contributed in shaping trust. Although previous research has shown that trust is a fairly stable variable, there are also studies indicating that trust can be both strengthened and weakened during major crises (Devine et al., 2021; Thoresen et al., 2021).

The COVID-19 pandemic is a massive crisis that has shaken the world and inflicted great social and economic costs on both society and individuals. While an increased sense of "togetherness" and "rally-round-the-flag" mentality is often seen in times of major crisis, it is unclear whether this is the case in the current crisis (Devine et al., 2021). The outbreak and rapid spread of COVID-19 may have undermined peoples' trust in experts and politicians involved in the response effort. Most countries have not been able to control the pandemic, many people have

\section{REFERENCES}

Algan, Y., and Cahuc, P. (2013). "Trust, growth and well-being: new evidence and policy implications," in Handbook of Economic Growth, Vol. 2A, eds P. Aghion and S. Durlauf (Amsterdam: Elsevier).

Arachchi, J. I., and Managi, S. (2021). The role of social capital in COVID-19 deaths. BMC Public Health 21, 434. doi: 10.1186/s12889-021-10475-8

Bargain, O., and Aminjonov, U. (2020). Trust and compliance to public health policies in times of COVID-19. J. Public Econ. 192, 104316. doi: $10.1016 /$ j.jpubeco.2020.104316

Blair, R. A., Morse, B. S., and Tsai, L. L. (2017). Public health and public trust: survey evidence from the Ebola Virus Disease epidemic in Liberia. Soc. Sci. Med. 27, 89-97. doi: 10.1016/j.socscimed.2016.11.016

Chuang, Y. C., Huang, Y. L., Tseng, K. C., Yen, C. H., and Yang, L. H. (2015). Social capital and health-protective behavior intentions in an influenza pandemic. PLoS ONE 10, e0122970. doi: 10.1371/journal.pone.0122970

Devine, D., Gaskell, J., Jennings, W., and Stoker, G. (2021). Trust and the coronavirus pandemic: what are the consequences of and for trust? An early review of the literature. Polit. Stud. Rev. 19, 274-285. doi: $10.1177 / 1478929920948684$

Díaz de León-Martínez, L., de la Sierra-de la Vega, L., Palacios-Ramírez, A., Rodriguez-Aguilar, M., and Flores-Ramírez, R. (2020). Critical review of social, environmental and health risk factors in the Mexican indigenous population and their capacity to respond to the COVID-19. Scie. Total Environ. 733, 139357. doi: 10.1016/j.scitotenv.2020.139357

Earle, T.C. (2010). Trust in risk management: A model-based review of empirical research. Risk Anal. 30, 541-74. doi: 10.1111/j.1539-6924.2010.01398.x

Elgar, F. J., Stefaniak, A., and Wohl, M. J. A. (2020). The trouble with trust: Timeseries analysis of social capital, income inequality, and COVID-19 deaths in 84 countries. Soc. Sci. Med. 123, 113365. doi: 10.1016/j.socscimed.2020.113365 not received the necessary health care, and many have lost their jobs and income. A growing number of countries have also experienced widespread social protests against the government, sometimes followed by counter-protests. This has contributed to reinforcing the political polarization and reduction in social trust that many countries experienced even before the pandemic.

We still need to acquire more knowledge about how different dimensions of trust affect risk perception and behavior during pandemics and crises. The purpose of this article is to contribute to this. To be prepared for the next crisis, we also need to know more about how the COVID-19 pandemic has affected trust in society, and how we can rebuild trust where it has eroded. We believe that this question will be researched intensively in the years to come.

\section{DATA AVAILABILITY STATEMENT}

The original contributions presented in the study are included in the article/supplementary materials, further inquiries can be directed to the corresponding author/s.

\section{AUTHOR CONTRIBUTIONS}

JR conceptualized the research paper, contributed to manuscript writing, data gathering, and interpretation of results. KR contributed to manuscript writing, data analysis, and interpretation. JW and MC contributed to data gathering and critical editing. All authors contributed to the article and approved the submitted version.

Fehr, E., and Gächter, S. (2002). Altruistic punishment in humans. Nature 415, 137-140. doi: 10.1038/415137a

Fischbacher, U., Gächter, S., and Fehr, E. (2001). Are people conditionally cooperative? Evidence from a public goods experiment. Econ. Lette. 71, 397-404. doi: 10.1016/S0165-1765(01)00394-9

Freimuth, V. S., Musa, D., Hilyard, K., Quinn, S. C., and Kim, K. (2014). Trust during the early stages of the $2009 \mathrm{H} 1 \mathrm{~N} 1$ pandemic. J. Health Commun. 19, 321-339. doi: 10.1080/10810730.2013.811323

Fukuyama, F. (1995). Trust. The Social Virtues and the Creation of Prosperity. New York, NY: The Free Press.

Gilles, I., Bangerter, A., Clemence, A., Green, E. G. T., Krings, F., Staerkle, C., et al. (2011). Trust in medical organizations predicts pandemic (H1N1) 2009 vaccination behavior and perceived efficacy of protection measures in the Swiss public. Eur. J. Epidemiol. 26, 203-210. doi: 10.1007/s10654-011-9577-2

Helliwell, J. F., Huang, H., Wang, S., and Norton, M. (2021). "World happiness, trust and deaths under COVID-19," in Chapter 2 in Helliwell, eds J. F. Layard, R. Sachs, J. Jan-Emmanuel De Neve. World Happiness Report 2021 (New York, NY: Sustainable Development Solutions Network).

Herrmann, B., and Thöni, C. (2009). Measuring conditional cooperation: a replication study in Russia. Exp. Econ. 12, 87-92. doi: 10.1007/s10683-008-9197-1

Hudson International Group (2021). The 2021 STC Health Index. Available online at: https:/globalresidenceindex.com/hnwi-index/health-index/ (accessed August 12, 2021).

IMF (2021). World Economic Outlook. Recovery During a Pandemic: Health Concerns, Supply Disruptions, and Price Pressures. Washington, DC: International Monetary Fund.

Lazzarini, S. G., Miller, G. J., and Zenger, T. R. (2008). Dealing with the paradox of embeddedness: The role of contracts and trust in facilitating movement out of committed relationships. Organ. Sci. 19, 709-728. doi: 10.1287/orsc.1070.0336 
Medina, M. A. (2020). Age As a Risk Factor of COVID-19 Mortality in the Philippines. Available online at: https://ssrn.com/abstract=3579145

NOU (2021). Myndighetenes håndtering av koronapandemien - Rapport fra Koronakommisjonen. Norges Offentlige utredninger nr. 6. Oslo: Departementenes servicesentral.

OECD (2020). Health at a Glance. Paris: OECD.

Olu, O. O., Lako, R., Wamala, J. F., Ramadan, P. O., Ryan, C., Udenwese, I., et al. (2020). What did we learn from preparing for cross-border transmission of Ebola virus disease into a complex humanitarian setting - the Republic of South Sudan? Infect. Dis. Poverty. 9, 40. doi: 10.1186/s40249-020-0 0657-8

Ostrom, E. (2003). "Toward a behavioral theory linking trust, reciprocity, and reputation," in Trust and Reciprocity: Interdisciplinary Lessons from Experimental Research, eds E. Ostrom and J. Walker (New York, NY: Russel Sage Foundation).

Poortinga, W., and Pidgeon, N. F. (2003). Exploring the dimensionality of trust in risk regulation. Risk Anal. 23, 961-972. doi: 10.1111/1539-6924.00373

Prati, G., Pietrantoni, L., and Zani, B. (2011). Compliance with recommendations for pandemic influenza H1N1 2009: the role of trust and personal beliefs. Health Educ. Res. 26, 761-769. doi: 10.1093/her/cyr035

Putnam, R. (2000). Bowling Alone: The Collapse and Revival of American Community. New York, NY: Simon and Schuster.

Rahmandad, H., Lim, T. Y., and Sterman, J. (2021). Behavioral dynamics of COVID-19: estimating under-reporting, multiple waves, and adherence fatigue across 92 nations. Syst. Dynam. Rev. 37, 5-31. doi: 10.1002/sdr.1673

Ritchie, H., Mathieu, E., Rodés-Guirao, L., Appel, C., Giattino, C., OrtizOspina, E., et al. (2021). Cumulative Confirmed COVID-19 Deaths Per Million People. Available online at OurWorldInData.org. https://ourworldindata.org/ coronavirus (accessed September 28, 2021).

Rothstein, B. (2011). The Quality of Government: Corruption, Social Trust and Inequality in International Perspective. Chicago: Chicago University Press.

Rubin, G. J., Amlôt, R., Page, L., and Wessely, S. (2009). Public perceptions, anxiety, and behaviour change in relation to the swine flu outbreak: cross sectional telephone survey. BMJ. 339, b2651. doi: 10.1136/bmj.b2651

Siegrist, M., and Bearth, A. (2021). Worldviews, trust, and risk perceptions shape public acceptance of COVID-19 public health measures. Proc. Natl. Acad Sci. USA. 118, 1-6 doi: 10.1073/pnas.2100411118

Siegrist, M., and Cvetkovich, G. (2000). Perception of hazards: the role of social trust and knowledge. Risk Anal. 20, 713-720. doi: 10.1111/0272-4332. 205064

Siegrist, M., Luchsinger, L., and Bearth, A. (2021). The impact of trust and risk perception on the acceptance of measures to reduce COVID-19 cases. Risk Anal. 41, 787-800. doi: 10.1111/risa.13675

Siegrist, M., and Zingg, A. (2014). The role of public trust during pandemics: implications for crisis communication. Eur. Psychol. 19, 23-32. doi: 10.1027/1016-9040/a000169

Tang, C. S. -K., and Wong, C. -Y. (2005). Psychosocial factors influencing the practice of preventive behaviors against the severe acute respiratory syndrome among older chinese in Hong Kong. J. Aging Health. 17, 490-506. doi: $10.1177 / 0898264305277966$

Terpstra, T. (2011). Emotions, trust, and perceived risk: affective and cognitive routes to flood preparedness behavior. Risk Anal. 31, 1658-1675. doi: 10.1111/j.1539-6924.2011.01616.x

Thoresen, S., Blix, I., Wentzel-Larsen, T., and Birkeland, M. S. (2021). Trusting others during a pandemic: investigating potential changes in generalized trust and its relationship with pandemic-related experiences and worry. Front. Psychol. 12, 698519. doi: 10.3389/fpsyg.2021.698519

Torsvik, G. (2000). Social capital and economic development: a plea for the mechanisms. Rational. Soc. 12, 451-476. doi: 10.1177/104346300012004005
United Nations (2021). World Population Prospects 2019. Department of Economic and Social Affairs. Population Dynamics. Available online at: https:// population.un.org/wpp/DataQuery/ (accessed March 14, 2021).

Uslaner, E. M. (2002). The Moral Foundation of Trust. Cambridge: Cambridge University Press.

Volk, S., Thöni, C., and Ruigrok, W. (2012). Temporal stability and psychological foundations of cooperation preferences. J. Behav. Or. 81, 664-676. doi: 10.1016/j.jebo.2011.10.006

Warren, G. W., and Lofstedt, R. (2021). Risk communication and COVID19 in Europe: lessons for future public health crises. J. Risk Res. 24, 3-4. doi: $10.1080 / 13669877.2021 .1947874$

Wellcome Trust and The Gallup Organization Ltd. (2019). Wellcome Global Monitor, 2018. [data collection]. 2nd Edition. UK Data Service. SN: 8466. Available online at: https://beta.ukdataservice.ac.uk/datacatalogue/studies/ study?id=8466\#!/details (accessed March 14, 2021).

Weninger, Q. (1998). A General Approach for Estimating the Translog Function in the Presence of Zero-Value Arguments: ISU General Staff Papers 19981212080000133. Department of Economics, Iowa State University, United States.

WHR (2021). World Happiness Report 2021. New York, NY: Sustainable Development Solutions Network.

Wollebæk, D., Enjolras, B., Fladmoe, A., and Steen-Johnsen, K. (2020). Tillit og bekymring: Hva avgjør om folk følger koronarådene? Available online at: https://www.samfunnsforskning.no/sivilsamfunn/publikasjoner/hovedfunn/ korona-tillit-og-bekymring/tillit-og-bekymring-hva-avgjor-om-folk-folgerkoronaradene.pdf (accessed September 28, 2021).

Wong, C. M. L., and Jensen, O. (2020). The paradox of trust: perceived risk and public compliance during the COVID-19 pandemic in Singapore. J. Res. 23, 1021-1030. doi: 10.1080/13669877.2020.1756386

World Bank (2021a). World Development Indicators Database. Available online at: https://data.worldbank.org/indicator/NY.GDP.PCAP.PP.KD (accessed March $14,2021)$.

World Bank (2021b). Population Density (People per sq. $\mathrm{km}$ of Land Area). Available online at: https://data.worldbank.org/indicator/EN.POP. DNST (accessed March 14, 2021).

World Factbook (2021). Land Borders. Available online at: https://web.archive. org/web/20160408145646/https://www.cia.gov/library/publications/ (accessed March 14, 2021).

Yamagishi, T. (2011). Trust. The Evolutionary Game of Mind and Society. London: Springer.

Conflict of Interest: The authors declare that the research was conducted in the absence of any commercial or financial relationships that could be construed as a potential conflict of interest.

Publisher's Note: All claims expressed in this article are solely those of the authors and do not necessarily represent those of their affiliated organizations, or those of the publisher, the editors and the reviewers. Any product that may be evaluated in this article, or claim that may be made by its manufacturer, is not guaranteed or endorsed by the publisher.

Copyright $\odot 2022$ Reiersen, Roll, Williams and Carlsson. This is an open-access article distributed under the terms of the Creative Commons Attribution License (CC $B Y)$. The use, distribution or reproduction in other forums is permitted, provided the original author(s) and the copyright owner(s) are credited and that the original publication in this journal is cited, in accordance with accepted academic practice. No use, distribution or reproduction is permitted which does not comply with these terms. 